\title{
Analysing The Concept of Place Attachment in The Context of Spatial Factors: Kuzguncuk, Istanbul
}

\section{Dilek Özdemir Darby Tuğçe Özata**}

\section{Abstract}

In contemporary globalised cities it has become increasingly important, for those of us who live in monotonous so-called cloned-environments, to find a sense of place we can identify with. When ties between inhabitants and places are disrupted, people are estranged from their neighbourhoods. As a result, not only people's relations with places are harmed, but also their social relations are affected, leading to isolation, alienation and socio-economic disruption.

The causes of these relations are analysed through the concept of place attachment. Since the 1970s, research on place attachment has grown considerably. These studies are mostly focused on sense awareness and affectiveness, with the physical attributes of places accorded lesser attention (Lewicka, 2011). In a similar vein Christopher Alexander (et al, 1977) has asserted that, when studying place attachment, influences associated with human feelings only comprise ten percent of total influences, while the rest derive from the physical characteristics of places. And yet these are the least examined objects of study.

In this context, the aim of this paper is to examine more closely the spatial qualities of places in the formation of place attachment. For the study, a long-established neighbourhood of Istanbul, Kuzguncuk, has

Keywords: Place attachment, urban design, place-making, sense of place, urban image

*Assoc. Prof., Yeditepe University, Department of Architecture, Istanbul

E-mail:dilekdarby@gmail.com

Orcid ID: http://orcid.org/0000-0001-8168-

0463

**Res.Asst., Yeditepe University, Department of Interior Architecture, Istanbul E-mail: tugceozt@hotmail.com 
been chosen to analyse the works of Christopher Alexander, Kevin Lynch, Jane Jacobs and John Montgomery. As a result, a matrix showing the spatial/physical qualities which have allowed the inhabitants of Kuzguncuk to develop a stronger attachment to their neighbourhood will be presented.

\section{INTRODUCTION}

Since the 1970s, research on place attachment (PA) has grown considerably, with a contribution from academics in various fields (Lewicka, 2011). Before analysing the meaning of PA it is important to define "place". For Tuan (1977) 'place is the humanized space'. Place only acquires meaning when people differentiate limitless space with their topographical understanding, memories, and actions, etc. Therefore, a place has three dimensions, 'physical (form and space), functional (activities) and psychological (emotion, cognition)' (Jelley, 2013, p.1). The meaning of place changes through time and context, therefore it is not static (Wolf et al. 2014). For Shumaker and Taylor (1983) PA occurs when there is a bond between the environment and the person. Rilley (1992) describes place attachment as an emotional relationship between people and places through cognitions, judgments, and decisions. According to Low and Altman (1992) place attachment and place identity are interrelated issues, since they are closely related to the issue of identity of individuals, groups, communities and cultures. Biological, environmental-spatial, psychological and sociocultural factors are influential in the formation and maintenance of the sense of place attachment and place identity. Scannell and Gilford (2010) propose a tripartite chart and define PA at two levels, individual and group. At the individual level Manzo (2005) suggests that personal experience gives a place its meaning, and although sometimes a given place may be uninspiring, experience can make it meaningful. These studies are important because in contemporary globalised cities, when ties between inhabitants and places are being disrupted, people are estranged from their neighbourhoods. As a result, not only people's relations with places are harmed, but also their social relations are affected, leading to isolation and alienation.

According to Lewicka (2011), when studying the roots of PA the psychological side of attachment has been the main focus, and she refers to Christopher Alexander's (et al. 1977) seminal book, Pattern Language, to further discuss the spatial/physical qualities of the built environment in order to understand the spatial dimension of the PA. According to Alexander (et al. 1977), when studying place attachment, human feelings only comprise $10 \%$ of total effects or influences, while the rest derive from the physical 
characteristics of places. And yet these are the least examined objects of study. In the context of this account, the aim of this study is to find out which physical/spatial elements may be fostering a feeling of place attachment for those people visiting and residing in a place. As a case study, a historical neighbourhood on the Asian side of Istanbul, Kuzguncuk, has been chosen, and to test the validity of this argument, 400 surveys were conducted among inhabitants (200) and visitors (200). The survey results demonstrated a high level of place attachment to the neighbourhood, especially to its physical features. Subsequently, the spatial qualities of the neighbourhood have been examined in the light of the work of four renowned urbanists and architects.

\section{PLACES WITH STRONG IMAGES AND IDENTITY: SOME THEORETICAL APPROACHES}

\section{Christopher Alexander and the Pattern Language}

In the second half of the twentieth century, various theories have been developed to assist architects and planners to design urban spaces. Among them, the architect Christopher Alexander is perhaps one of the most influential with respect to his seminal book, A Pattern Language (et al. 1977). In this study, Alexander gave examples of detailed solutions for buildings, cities, neighbourhoods, houses; gardens and rooms that are made up of patterns ranging from large to small are defined. He described 253 pattern languages in his book. It is designed with the idea of applying various combinations of formats in this language. Patterns start with city scale and end with neighbourhood scale, building clusters, buildings, rooms and construction details. For example, pattern no.61- 'Small Public Square' is in relation to the upper and lower scale patterns. Therefore, a small public square should be designed in considering the other patterns, namely, Activity Node, Promenade, Work Community, Identifiable Neighbourhood, Small Public Squares, Pedestrian Density, Activity Pockets, Positive Outdoor Space, Hierarchy of Open Space, Building Fronts, Stair Seats, and Something Roughly in the Middle (Alexander et al.1977). When these patterns are connected to each other they create a small public square. A pattern is complete only when it is together with the other patterns. There is no individual pattern independent from the others. This is a process which needs to be discovered by the designer, and there is no imposition.

\section{Kevin Lynch and the Image of the City}

Kevin Lynch's eminent book, the Image of the City (1960) is one of the earliest studies that have experimentally analysed urban space through the lenses of legibility and imageability. According to Lynch, cities are important and have views that must be 
perceived, remembered and enjoyed. At the same time, it is a significant design problem to give the city a visible form. What Lynch tried to achieve is the well-designed town that possesses legibility. Lynch examined the visual quality of cities based on the mental maps of their inhabitants. According to Lynch, imageability requires these to be clear, legible and visible. Lynch proposed that the contents of the urban image can be classified under five headings; paths, edges, nodes, districts, and landmarks. These elements co-exist with each other, i.e., a path may lead the pedestrian to a node in the middle of which a landmark might be located, and all of these may be located in a district. According to Lynch, landmarks are the elements that help to define legibility in cities. However, since they are external items, the observer cannot normally get into them. These are mostly easily identifiable physical formations; a building, a sign, a shop, or a steep slope. Other sign items are mainly visible from restricted areas. Examples include signboards, shop fronts, trees, and other urban details, which are visible to pedestrians. They are often used as clues to the understanding of urban identity. People in cities use them as a guide as they learn the city better. Lynch says that a well-designed urban/environmental image gives people the feeling of safety/security. Moreover, if a person is surrounded by a good urban image, s/he can establish better relations with others. A clearly identifiable and imageable urban landscape may therefore enhance the intensity and the depth of the experience of oneself (Lynch, 1960).

\section{Jane Jacobs and the cities for people}

Jane Jacobs (1961) is without doubt one of the most influential figures of twentieth century urbanism with her ideas on mixeduse neighbourhoods, population density, pedestrian-biased streets and economic diversity. According to Jacobs, when planning a city, elevating the vitality of daily life in the formulation of plans, targeting the aspirations of the middle classes, avoiding boring and monotonous social housing estates, promoting social centres to attract people for entertainment, and providing pedestrian streets that remain preferred by visitors should be the main purposes of planning. Jacobs proposed (1961) 'a wide range of diversity in functions/uses; various local/independent shops; flexibility in opening-closing hours, the presence of street markets; cinemas, theatres, wine houses, cafés, pubs, restaurants, and meeting places that serve different types of food, serving every budget; areas that allow people to follow (including gardens, squares and other cultural activities); the possession of a variety of land so that development and small-scale land investment can be achieved; the availability of housing and shops with differing price and rental ranges, a degree of self-reliance and 
innovation in the new architecture, and active street life and active building fronts'. Finally, to achieve these goals a sufficient population density should be achieved and maintained (Jacobs, 1961).

\section{John Montgomery and the place-making principles}

John Montgomery is an urbanist and planner who extensively published on the subject of successful urban design. In his widelyquoted essay 'Making a City: Urbanity, vitality and urban design' (1998) Montgomery claimed that creating the perception of place is much more complex than planning a city. Creating spatial perception requires knowledge, understanding, talent and judgement. In urban design work, to reach urban quality the designer should consider the larger picture rather than focusing on the individual properties of the buildings or streets. The physical elements, such as landmarks, open spaces, meeting places, architectural form etc., should be combined with each other in view of the psychology of place to produce urban quality. Therefore, he asserts that urban quality is related to 'the social, psychological and cultural dimensions of place'. He states that in successful public places, the possibilities for all kinds of transaction (social, cultural, and economic) should exist. Without establishing a multi-layered and complex system of transactions, a good/successful urban place cannot be created. In the course of time, the users frequenting a place develop a sense of place which ultimately ends up with their belonging to a place. Therefore, in order to create sense of place, form (physical elements), activity (diversity, street life, café culture, events, etc) and image (cognition, perception, and knowledge) should intermingle with each other.

\section{KUZGUNCUK: PAST AND PRESENT}

Kuzguncuk, which was developed in a valley opening to the Bosphorus, is a settlement between Üsküdar, Paşalimanı and Beylerbeyi and is located in northwest-southeast direction. The neighbourhood's location is very favourable because of its proximity to the Bosphorus Bridge. In spite of this locational advantage, the area is protected from the unsupervised building construction along the Bosphorus. Therefore it is a quiet/tranquil neighbourhood as well as being centrally located.

In the 18th and 19th centuries, the social space in Istanbul consisted of ethnic communities. In Kuzguncuk Muslims and nonMuslims lived together for many years. Kuzguncuk is known as the first district where the Jews settled on the Anatolian side. Although the exact date on which they first settled here is unknown, Kuzguncuk was recognised as a Jewish village in 
seventeenth century sources. The area, for a long time, accommodated Jews, Armenians and Turks (Uzun, 2001).

The transformation of the neighbourhood in the twentieth century started with the acquisition of an old house at Üryanizade Street by Cengiz Bektaş at the end of the 1970's. Cengiz Bektaş is a well-known architect with many books and articles on architecture, urban planning, environmental and architectural conservation. After Cengiz Bektaş's move to the neighbourhood, Kuzguncuk became a favoured settlement by architects, artists and writers. However, as the area became popular, the demand for Kuzguncuk residence from those located in other districts of Istanbul increased, and there occurred a noticeable increase in property prices (Uzun, 2001).

Despite not receiving the financial support he requested from the banks, Cengiz Bektaş became successful in mobilizing the community in organizing socio-cultural events. One day in 1984, Bektaş set a shadow play show for children on the stairs of Bereketli Street. From that day onwards, many other activities were performed in the neighbourhood. Some of these were cultural activities such as games for children, workshops and a summer school. Alongside these cultural activities, many facilities around the area have also developed. For example, a basketball court was established, a street theatre was built, and the place where the garbage was previously collected was transformed into a playground, while the empty walls of Üryanizade Street and

${ }^{1}$ Interview with the architect Cengiz Bektaş on 16 January, 2015. some other areas were painted by children with the help of the painters of the area ${ }^{1}$.

In 1986, the vegetable garden (Bostan) was opened to serve the local community as a recreational area. Since then, a struggle by Kuzguncuk locals has been continuing to save this garden from being re-developed as a school, a hospital, or for other nonrecreational uses. Finally in 2014, it was decided and announced that the Bostan would remain as a vegetable garden, and a year later, in 2015 it was opened as an urban agriculture field. Bostan has always been an important gathering place for the local community of Kuzguncuk. It represents certain relinquished social and psychological values and spatial qualities which have been long lost in many neighbourhoods of Istanbul. Therefore, the struggle of Kuzguncuk's inhabitants for many years to maintain the Bostan can be seen as a sign of strong place attachment. 


\section{LOOKING FOR THE ROOTS OF PLACE ATTACHMENT IN KUZGUNCUK}

Spatial characteristics referred to in the works of four prominent urbanists, that might be applied to Kuzguncuk, are listed in the following table. (See Table 1)

Table 1: The physical qualities of spaces influencing the formation of place attachment

\begin{tabular}{|c|c|c|c|c|}
\hline & $\begin{array}{l}\text { Christopher } \\
\text { Alexander }\end{array}$ & $\begin{array}{l}\text { Kevin } \\
\text { Lynch }\end{array}$ & $\begin{array}{l}\text { Jane } \\
\text { Jacobs }\end{array}$ & $\begin{array}{c}\text { John } \\
\text { Montgomery }\end{array}$ \\
\hline Location & & $\mathrm{x}$ & & \\
\hline $\begin{array}{l}\text { Seaside/waterfr } \\
\text { ont }\end{array}$ & & $\mathrm{x}$ & & $\mathrm{x}$ \\
\hline Public squares & $\mathrm{x}$ & $\mathrm{x}$ & & $\mathrm{x}$ \\
\hline $\begin{array}{l}\text { Recreational } \\
\text { areas }\end{array}$ & $\mathrm{x}$ & $\mathrm{x}$ & & $\mathrm{x}$ \\
\hline $\begin{array}{l}\text { Neighbourhood } \\
\text { parks }\end{array}$ & $\mathrm{x}$ & & $\mathrm{x}$ & $\mathrm{x}$ \\
\hline Short streets & $\mathrm{x}$ & $\mathrm{x}$ & $\mathrm{x}$ & $\mathrm{x}$ \\
\hline $\begin{array}{l}\text { Pedestrian } \\
\text { Streets }\end{array}$ & $\mathrm{x}$ & $\mathrm{x}$ & $\mathrm{x}$ & $\mathrm{x}$ \\
\hline Landmarks & & $\mathrm{x}$ & & $\mathrm{x}$ \\
\hline Mixed use & & & $\mathrm{x}$ & $\mathrm{x}$ \\
\hline Street cafes & $\mathrm{x}$ & & $\mathrm{x}$ & $\mathrm{x}$ \\
\hline $\begin{array}{l}\text { Individually- } \\
\text { owned shops }\end{array}$ & $\mathrm{x}$ & & $\mathrm{x}$ & $\mathrm{x}$ \\
\hline Historic pattern & & $\mathrm{x}$ & $\mathrm{x}$ & \\
\hline $\begin{array}{l}\text { Architectural } \\
\text { styles }\end{array}$ & $\mathrm{x}$ & $\mathrm{x}$ & $\mathrm{x}$ & $\mathrm{x}$ \\
\hline Building scale & $\mathrm{x}$ & & $\mathrm{x}$ & $\mathrm{x}$ \\
\hline Human scale & $\mathrm{x}$ & & $\mathrm{x}$ & $\mathrm{x}$ \\
\hline Doors-windows & $\mathrm{x}$ & $\mathrm{x}$ & & \\
\hline Ornament & $\mathrm{x}$ & $\mathrm{x}$ & & $\mathrm{x}$ \\
\hline Street Furniture & $\mathrm{x}$ & $\mathrm{x}$ & & $\mathrm{x}$ \\
\hline Colour & $\mathrm{x}$ & $\mathrm{x}$ & & \\
\hline Lighting & $\mathrm{x}$ & & & $\mathrm{x}$ \\
\hline Pavement & $\mathrm{x}$ & $\mathrm{x}$ & & $\mathrm{x}$ \\
\hline
\end{tabular}

Proximity. The availability of the public transportation and shared taxis (dolmuş) increases the locational advantage of Kuzguncuk, which is located between Üsküdar centre (the second largest retail concentration on the Asian side of the city) and Beylerbeyi, another historical neighbourhood. Üsküdar is also an easily accessible district because of its proximity to the Bosphorus Bridge. Seaside/Waterfront: The Çınaraltı square in Kuzguncuk 
and the pier bear the characteristic of connection nodes with the shore of the Bosphorus. Many people come to visit or travel in this area because of proximity to the sea, attractive scenery, and entertainment and leisure facilities. This suggests that being close to water is very important, and it encourages opportunities for inhabitants and visitors to socialize, to see and be seen. As Lynch as noted nodes are points where roads intersect, and a nodal point can be an intersection for both pedestrians and vehicles alike. The existence of nodes, such as public squares, recreational areas and parks in Kuzguncuk are the other spatial elements which help to foster social relations in the neighbourhood. As Wolf (et al. 2014) noted, greener neighbourhoods with green common areas make it possible to form strong social bonds among the local community. In Kuzguncuk, Paşalimanı, İcadiye Streets and Çınaraltı square are the most densely populated locations and represent a perfect node for pedestrians and traffic. Another important node and point of visual reference in Kuzguncuk is the popular and accessible Vegetable Garden (Bostan). The existence of pedestrian streets and short streets are also the two other important design features mentioned by all four theoreticians. In this design feature, once again, the possibilities for the creation of meeting points for pedestrians can be realized. These nodal points create opportunities for people to come together to organize events and activities and to create their own experiences, memories, and emotions, which in turn foster strong place attachment.(See Figure 1)

The historic plane tree at the intersection of the Pasalimani and Icadiye Streets at Kuzguncuk and the Dilim patisserie at the same corner can be described as local landmarks. It is not possible to think of the neighbourhood without recalling this impressive tree. It can be regarded as an important landmark and visual anchor, given that it is located in a spot that cannot be missed easily. According to Lynch, continuity is a functional necessity. People always rely on this feature. The main requirement is the continuity of the road itself or road coverage, and people tend to think about the direction of the road and where it starts and ends. We can see clearly that Kuzguncuk has a dense network of roads and pavements along all its streets.

Individually-owned shops and street cafes are also places for people to interact, socially, culturally and economically. These features are repeatedly emphasized by Montgomery, Jacobs and Alexander. The existence of individually-owned shops is especially important, because people may not be able to establish memories or experiences in shops which are part of the 
national/international chains which stereotype shop fronts and standard services.

The rest of the features, historic fabric, architectural style, and building and human scales are also important to create a sense of place, where people like to stay, socialize and live through their experiences and memories. To complete this milieu, the architectural details (doors, windows, ornaments), and street furniture, together with colour, lighting, and pavement design, should be planned in detail so that people would like to return to this milieu again and again. (See Figure 1)

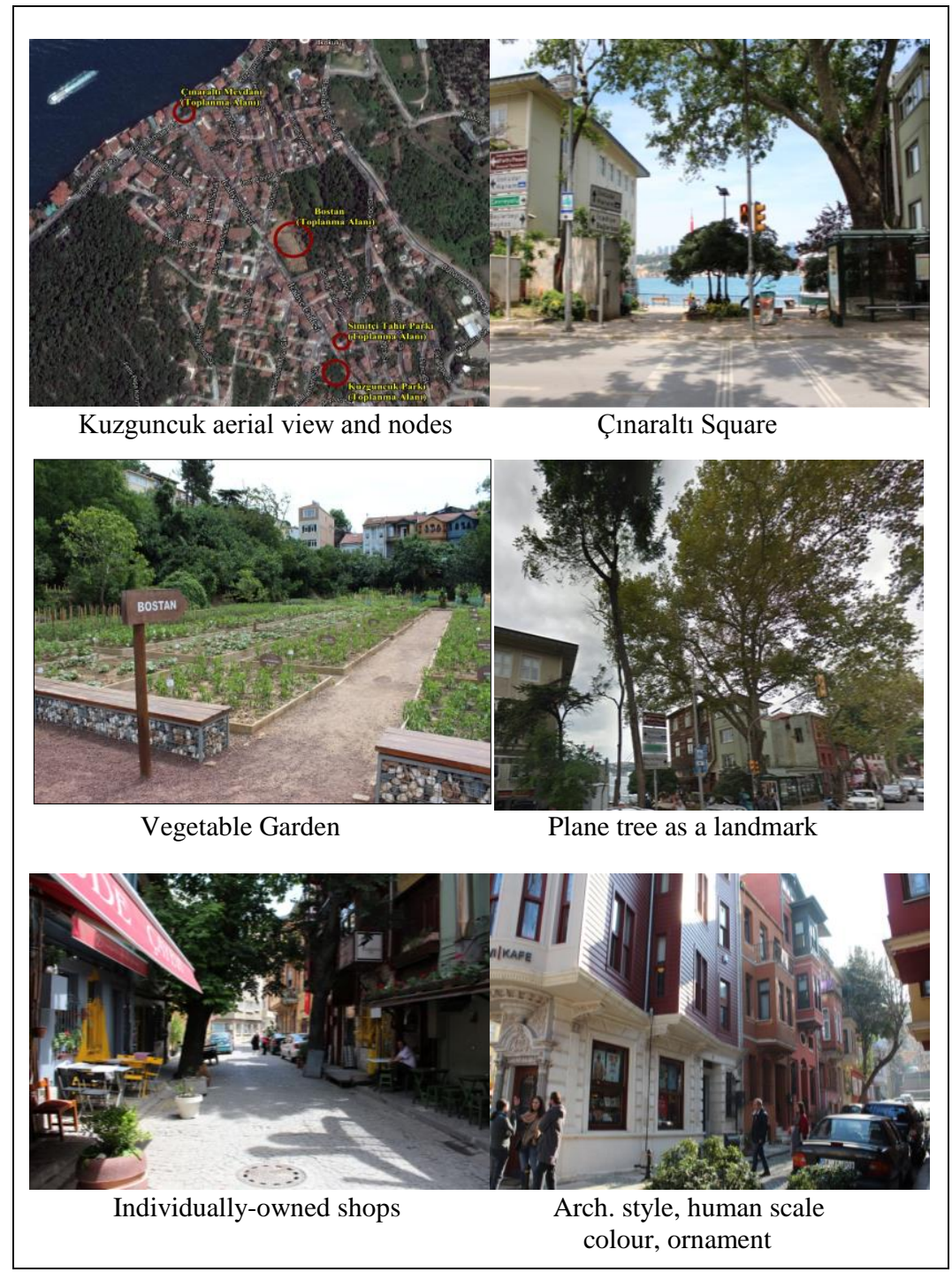

\section{CONCLUSION}

Attachment to a place refers to the emotional commitment to the physical environment in which people live, or relate-to. One of the most important factors behind people's commitment is socialization. In order to be able to socialize, it is especially
Figure 1: Views of Kuzguncuk showing some spatial features related to place attachment (Photographs by Tuğçe Özata) 
important that there are small places where people are located at the seaside and where people spend quality time. Such places offer people a good view and socialization. These facilities are supported by the presence of public spaces, recreational areas and neighbourhood parks. Short-cuts are often used to encourage people to meet and communicate with each other without walking long distances.

The urban land use pattern should permit densities of people in places where activities might require sufficient numbers to congregate. In this respect, mixed-use areas attract more people than mono-functional areas. Even though it is an economic factor, mixed-use is very important in social terms as well. Street cafes also emerge as areas where people can socialize. Individuallyowned businesses offer special services provided by the owner of the shop to customers. This is a feature not possible to achieve in store chains. The special attention given by individually-owned stores is outside the standard customer buyer relationship. So it is very important.

Historical urban environments are mostly human scale, and people value such environments more than the colourless, often uninspiring high-rise buildings which are quite common nowadays in big cities, not least the mega-city of Istanbul. The latter make people feel intimidated by scale, and lost in a monotonous environment. The urban fabric should also provide a variety of different architectural styles with aesthetic charm and beauty. Ornaments on doors and windows are elements that visually contribute to environmental aesthetics. Street furniture is also important if it is well designed. It can be useful also to select various plant species, and ecologically suitable materials, to cover the ground. Places have emotional, behavioural and form-related meanings. This emotional attachment is often the result of affective spatial features which stimulate feelings of place attachment.

\section{ACKNOWLEDGEMENTS}

This article is prepared by expanding the proceeding presented in the ICONARCH III, held at Selçuk University in May 11th-13th, 2017. 


\section{REFERENCES}

Alexander, C., Ishikawa, S. and Silverstein, M. (1977). A Pattern Language: Towns, Buildings, Construction, Center for Environmental Structure, Berkeley.

Altman , I. and Low, S. M. (1992). Place Attachment: Human Behaviour and Environment, Advances in Theory and Research, Plenum Press.

Jacobs, J. (1961). Büyük Amerikan Şehirlerinin Ölümü ve Yaşamı, Vintage Books, London.

Jelly, E.S. (2013). A Study of Place Attachment, Master of Marketing - Research Thesis, School of Management and Marketing, University of Wollongong

Lewicka, M. (2011). Place attachment: how far have we come in the last 40 years?, Journal of Environmental Psychology 31, pp. 207-320, Elsevier Press.

Lynch, K. (1960). The Image of the City, MIT Press, Cambridge.

Manzo, L.C. (2005). For Better or Worse: Exploring Multiple Dimensions of Place Meaning. Journal of Environmental Psychology 25 (1), pp.67-86, Elsevier Press.

Montgomery, J. (1998). Making a city: Urbanity, Vitality and Urban Design, Journal of Urban Design 3, pp. 93-113, Taylor and Francis.

Uzun, C. N., (2001). Gentrification in Istanbul: A Diagnostic Study, Koninklijk Nederlands Aardrijkskunding Genootschap, Istanbul.

Wolf, K., Krueger, S., and Flora, K. (2014). Place Attachment and Meaning-A Literature Review. In Green Cities: Good Health. College of the Environment, University of Washington www.greenhealth.washington.edu (date of connection: 2017)

\section{Resume}

Dilek Özdemir Darby had her bachelor, masters and doctorate degrees from the City and Regional Planning of the Middle East Technical University. She had worked in the Architecture department of the Yeditepe University between 2000 and 2017. Between 2000 and 2010 she taught in project studios of the City and Regional Planning department of the Ylldız Technical University. Assoc.Prof.Özdemir-Darby currently works in the Urban Design and Landscape Architecture Department of the Yeditepe University, Istanbul. Her research interests are urban design, place attachment, urban regeneration, and urban development. 
Tuğçe Özata completed the double-major program of the Interior Architecture and Architecture departments at the Yeditepe University. She had her MSc degree in the Architecture program of the Yeditepe University. She is currently studying in the doctorate program of the Restoration and Conservation Department of the Mimar Sinan Fine Arts University, Istanbul. Her research interests are urban design, place attachment, conservation and restoration. 